\title{
China's climate and energy policy: at a turning point?
}

\author{
Gørild M. Heggelund ${ }^{1}$
}

Accepted: 25 January 2021 / Published online: 13 February 2021

(c) The Author(s), under exclusive licence to Springer Nature B.V. part of Springer Nature 2021

\begin{abstract}
How have 30 years of development in energy and climate policies influenced long-term trends in China and what does this imply for future climate policies? To answer the question, this article examines three decades of energy and climate policies in China. By providing an overarching review, it contributes new and updated research on drivers behind long-term climate policies and whether China's long-term emissions trend can be broken by placing greater emphasis on innovation, technology and low-carbon development. Importantly, it analyses the most recent policy developments in China, such as the likely effects of China's recent 2060 carbon neutrality goal. We conclude that after the Paris Agreement, the biggest policy change has been technological innovation in the power and transport sector. China has prioritized measures, laws and policies for developing renewable energy, especially solar and wind. China has also embraced the 'green growth' approach for responding to the challenges of climate change. These efforts have yielded results, and China has emerged as a world leader in renewable energy. However, there is still a long way to go. The upcoming 14th five-year plan will be critical for accelerating the energy transition, including setting a cap on coal in the national energy-transition strategy.
\end{abstract}

Keywords China $\cdot$ Climate policy $\cdot$ Energy policy $\cdot$ Carbon neutrality $\cdot$ Paris agreement

$\begin{array}{ll}\text { Abbreviations } \\ \text { CPC } & \text { Communist party of China } \\ \text { ETS } & \text { Emissions trading scheme } \\ \text { EVs } & \text { Electric vehicles } \\ \text { FYP } & \text { Five-year plans } \\ \text { GDP } & \text { Gross domestic product } \\ \text { GHG } & \text { Greenhouse gas } \\ \text { MEE } & \text { Ministry of ecology and environment } \\ \text { NDRC } & \text { National development and reform commission } \\ \text { NEA } & \text { National energy administration } \\ \text { NDC } & \text { Nationally determined contribution } \\ \text { NPC } & \text { National people's congress }\end{array}$

Gørild M. Heggelund

gheggelund@fni.no

1 The Fridtjof Nansen Institute (FNI), Fridtjof Nansens vei 17, P.O. Box 326, 1326 Lysaker, Norway 


\section{Introduction: purpose and scope}

In 2007, China surpassed the USA as the world's top greenhouse gas (GHG) emitter, and now accounts for nearly 28-30\% of total global emissions (Crippa et al. 2019; Le Quéré et al. 2018; PBL 2007). China's GHG emissions have grown rapidly since 1990, more than tripling by 2018. From a fairly modest start, China has become the worlds' largest emitter in less than two decades. Climate has moved up the agenda of the leadership's policy priorities, it has gradually introduced a more ambitious climate policy, as reflected in policy documents such as the five-year plans (FYPs). Moreover, China has emerged as the world leader in renewable energy, in particular solar and wind. The Covid-19 outbreak in spring 2020 brought a decline in emissions, but energy consumption has risen again since then.

Recently, China unexpectedly announced its goal of becoming carbon-neutral by 2060 and revised the goal to peak emissions before 2030 (changed from around 2030) (Ma 2020). This could spur domestic climate efforts, as a new set of policy measures and actions will be required to bring national carbon emissions to a peak, in accordance with commitments to the Paris Agreement (NDRC 2015).

This article contributes to new analysis on China's domestic energy and climate policies. With China's large emissions and role in addressing global climate change, it is particularly important to gain knowledge about the different forces shaping Chinese climate policy. Hence, our key research question is: how have 30 years of developments in energy and climate policies influenced long-term trends in China and what does this imply for future climate policies? To answer this question, we raise several sub-questions: strong economic growth fuelled by fossil energy has been the main driver behind the growth in emissions; how may this sharply increased attention to climate issues have affected emissions trajectories? And may this trend be broken, given China's recently announced 2060 carbon neutrality goal, which will require a very different approach to economic development and weight on renewable energy technology development? Finally, we examine the policy conditions of recession and economic recovery packages related to the Covid-19 crisis. China's economy has recovered much faster than that of most other countries. How has this affected the recovery packages? Will it stimulate the 'green growth' perspective-or continued heavy reliance on fossil fuels?

The article is structured in the following way: after presenting the analytical and methodological approach, we move on to major developments in the years leading up to the Paris Agreement (1990-2015). This period, with an awaking to the energy-related emissions and air pollution, provides a foundation for understanding the period after the Paris Agreement (2016-2020), which constitutes the main analysis. Here, the focus is on developments in the energy policy mix, including renewable energy and electric vehicles. Finally, in a forward-looking section, we discuss possible future energy and climate trajectories for China, 2020-2060.

\section{Brief analytical approach and methodology}

Numerous studies have examined China's climate and energy policies. Existing research has emphasized different aspects of China's climate policymaking, including its role in the global climate negotiations and the potential for leadership (Kopra 2019; Zhang et al. 2017; Hilton and Kerr 2017), a specific focus on energy and carbon emissions and energy 
consumption (Lin et al. 2018; Le Quéré et al. 2018; Jiang et al. 2018), and increasingly, on the transition to technology and green energy (Malcomson 2020; Korsnes 2020; Helveston and Nahm 2019). Our article provides a different approach: it is an overarching review of three decades of energy and climate policies; it contributes new and updated research on drivers behind long-term climate policies and whether China's long-term emissions trend can be broken by placing greater emphasis on innovation, technology and low-carbon development.

The analytical approach is introduced in the editorial article of this special feature (Andresen et al. 2020), hence a very brief introduction is given here. The IPCC identified population and energy use related to economic growth as the main and most immediate drivers of GHG emissions (IPCC 2014). This is clearly reflected in the experience gained from China's steep emissions growth over the past three decades, where economic growth has been the most important driver by far. Recently, China has emphasized technology development as a means of countering this undesirable trend and has also embraced the 'green growth' approach for responding to the challenges of climate change (He 2020).

Taking the above into account, policy instruments are deemed crucial for driving radical change-like supply-push policies directing support to low-carbon innovation, and demand-pull policies like effective carbon pricing (Eikeland and Skjærseth 2019). In terms of supply-push policies, China has become the world leader in technology investment and installed capacity in wind and solar power, as well as in introducing electrical cars (Korsnes 2020). As to demand-pull policies, a carbon-pricing approach is being developed through the emerging emissions trading scheme (ETS) regime (Heggelund et al. 2019). Further, considerable progress has been made in energy efficiency; and measures for countering air pollution have been important also for curbing $\mathrm{CO}_{2}$ emissions. However, all this has not been sufficient to counter the rise in emissions (prior to Covid-19), which illustrates the challenges of realizing the 'green growth' approach in practice.

As to the policy conditions needed to realize the necessary technological change towards a low-carbon-economy, we lack sufficient data regarding the two policy-mixes for promoting new business opportunities or ensuring 'energy justice'. However, China's consecutive FYPs set binding and indicative goals, and sectoral plans are important guiding documents for implementation. Long used as a key planning tool in China, with the same timeframe as the cycles adopted in the Paris Agreement, these have become significantly more ambitious, providing positive feedback. However, effective implementation by the central government is often prevented by resistance from lower levels of governance.

Regarding methodology, we have applied and combined several research methods that constitute the triangulation of the methodological approach. The article draws on first-hand Chinese language reports, official statements and policy documents as well as journal articles (Chinese and international). Second, our research is founded on the author's personal communication with key academics and experts in universities and think tanks on China's energy and climate policy over the past three decades. Moreover, our research is informed by personal work experience in climate change affairs in the UNDP in China over many years. Finally, we base our findings on the eight-year research programme CICEP, in which China is a key country. ${ }^{1}$

\footnotetext{
${ }^{1}$ Strategic Challenges in International Climate and Energy Policy (CICEP)—FNI. China's Domestic policy development—driving forces and long-term trajectories' is the research focus. Project period: 2011-2019.
} 


\section{Before Paris: changing gears on energy and climate policies (1990- 2015)}

In the early 1990s, climate change received scant attention and was largely viewed as a scientific issue for discussion in remote international negotiations. A shift came in the late 1990s, when China began mainstreaming and integrating climate change into its central economic development framework in response to various core drivers, such as energy security, air pollution, and health issues (Heggelund and Nadin 2017). During that period, we identified three important trends in climate and energy policy. First, with the growing awareness of energy-related emissions, climate change and its impacts on China, the National Climate Change Programme was issued in 2007, making climate change issues a national policy (NDRC 2007). Rapid energy consumption characterized the period 1990-2013. In particular, 2000-2013 was an energy-intensive growth period in China: coal consumption nearly tripled (Green and Stern 2016), followed by signs of a decline. Attempts to conserve energy and control emissions became a priority in several FYPs10th FYP (2000-2005), 11th (2006-2010) and 12th (2011-2015).

The 11th FYP continued the emphasis on energy efficiency as a means of reducing energy consumption. However, the command-and-control approaches traditionally applied in this period came under scrutiny due to shortcomings in attaining objectives. This led to a radical re-alignment at the start of the 12th FYP when low-carbon, green, sustainable development as well as market approaches were introduced (Heggelund et al. 2019). Yet, preferential policies to the coal sector continued, pushed by the state-owned enterprises and supported by local governments due to local economic interests (CREO 2018).

Second, the effects of serious air pollution became evident in this period. With recognition of the unsustainable focus on growth, and growing concern among the leadership and the public, 'capping coal' gradually became an option for reducing air pollution, which was especially serious in 2013 and 2014 (Ahlers and Shen 2018). In this period, smog and ultra-fine particles of less than 2.5 microns (PM2.5) concentrations in cities in northern China reached dangerous levels. In response, the State Council issued the Air Pollution Action Plan (2013-2017) with concrete objectives for improving air quality in the Beijing-Tianjin-Hebei area, the Yangtze River Delta and the Pearl River Delta (State Council 2013). Energy-related air pollution became an important driver for restructuring the energy sector through an energy revolution launched in 2014, as well as the New Normal (xin changtai) that emphasized more sustainable economic development and lower economic growth (NDRC/NEA 2017; CREO 2017).

Finally, market reform entered the stage in 2011, when China decided to establish a carbon market as part of its 12th FYP (2011-2015), recognizing the need to 'let the market play a fundamental role in resource allocation' (12th FYP, 2011, Chapter 1.1; NDRC 2011). This was in line with the deepening of market reform and economic restructuring, as decided at the Party 18th Communist Party Congress in November 2012 (China. org. 2012; CCPCC 2013). As a result, China began preparing a national emissions trading scheme (ETS), planned to begin operation in 2017. Seven pilots were launched in 2013 and 2014 to gain experience for use in the national ETS. ${ }^{2}$

${ }^{2}$ Beijing, Tianjin, Shanghai Guangdong, Shenzhen, Chongqing and Hubei. 


\section{After Paris: energy revolution, or return to coal? (2015-2020)}

China actively participated and contributed to the 2015 Paris Agreement and set climate goals to be achieved in national and sectoral five-year plans. Below we look into the significance of the Agreement for China's policies and achievements in the post-Paris period by analysing official Chinese policy documents.

\subsection{China's policy ambitions and efforts to address emissions post-Paris}

The Paris Agreement was clearly important for China. China submitted its Nationally Determined Contribution (NDC), aimed at peaking emissions 'around 2030 and making best efforts to peak early' (NDRC 2015), and carbon-emission intensity by $60-65 \%$ of 2005 levels. These objectives were developed in relation to the five-year planning cycle (Hart 2019), in this case the 13th FYP for Social and Economic Development (State Council 2016a). The sectoral 13th FYP for Energy Development (2016-2020) set a first-ever binding target for the share of coal in total energy consumption, at $58 \%$ or below (NEA 2017a), a goal China has achieved. By 2019, coal amounted to $57.7 \%$ of total energy consumption-down from 58-59\% in 2018 (NBS 2020a). Also, the 13th FYP for controlling GHG emissions was issued post-Paris. The plan refers to the Paris Agreement and the need to strengthen compliance work, make preparations for domestic implementation, and set objectives for energy consumption and emissions (State Council 2016b).

How has China managed to achieve this? Air pollution control and limiting coal consumption have been central here. The air pollution action plan (2013-2017) set clear goals. It was followed by the three-year air pollution action plan (2018-2020) to bring back blue skies (State Council 2018). Results include improvements in air quality in many cities: the switch to natural gas is one reason for this. Particularly since 2012-2014, there has been a rapid development; natural gas consumption increased by $18 \%$ in 2018, and import dependence rose to $45.3 \%$ (CREO 2019). Natural gas is largely viewed as a bridge fuel until more renewable sources can become available. According to official updates, by the end of 2018 , China had decreased its $\mathrm{CO}_{2}$ emissions per unit of GDP (carbon intensity) by $45.8 \%$ compared with the level in 2005 (MEE 2019) — thus, the objective of 40-45\% reduction of carbon intensity before 2020 as per the Copenhagen Accord (2009) was achieved ahead of schedule (NDRC 2010).

Beijing also pushed for a national emissions trading system (ETS) as one of several policy tools for reducing GHG emissions. In late 2017, the national carbon market was announced, starting with the power sector, the largest emitting sector. This was followed by a two-year trial period, with real trading set to begin in 2020 (see Fig. 1 on $\mathrm{CO}_{2}$-emitting sectors). A test of the national registry (in Hubei province) was performed recently, and the Ministry of Ecology and Environment approved 'Administrative Measures for carbon emission trading (Trial)' for its national ETS in January 2021 (Reklev 2020b; MEE 2021). The Measures will enter into force on 1 February and provide the legal basis for the national carbon market, a final step towards making the carbon market operational.

\subsection{Mixed signals on coal and challenges in implementing China's climate targets?}

Despite a $10 \%$ decrease in coal consumption in the past decade, after Paris the signals were mixed. Following a slowdown during 2013-2016, coal consumption and emissions rose again (Le Quéré et al. 2018; Kahya 2017). After a further increase of 1.5\% in 2017-2018, 


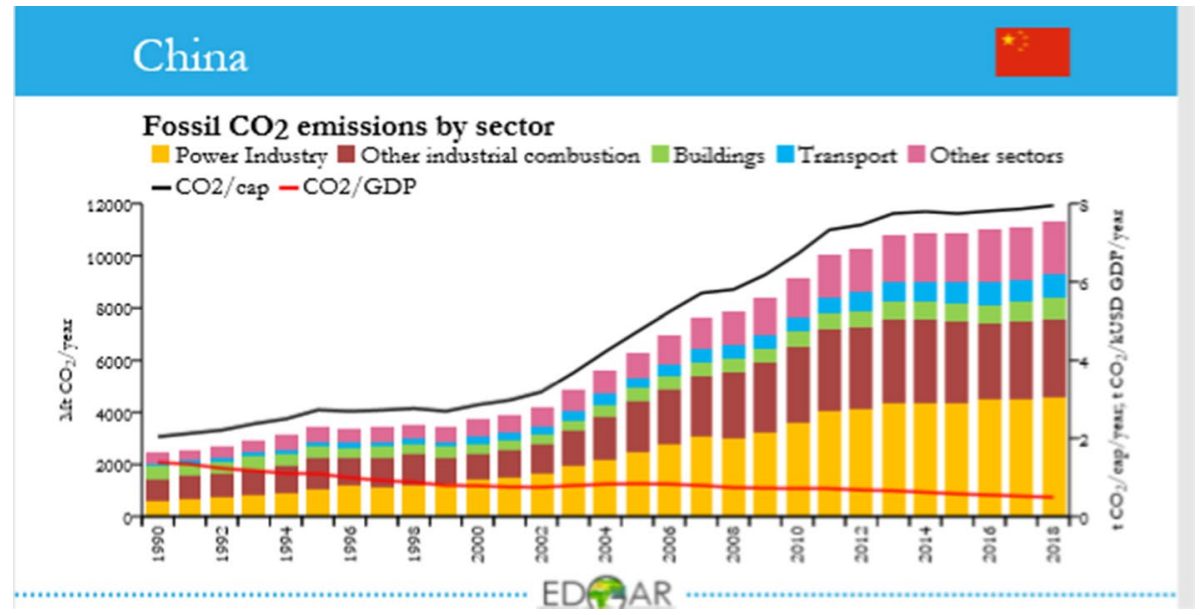

Fig. $1 \mathrm{CO}_{2}$ emissions by sector, 1990-2018. Source Crippa et al. (2019)

China accounted for 29.7\% of global emissions in 2018 (Crippa et al. 2019). Moreover, in 2014, in a move to decentralize decision-making, the central authorities gave provinces more autonomy to make investments, including the authority to approve new coal-fired power plants. This led to the approval of many new projects (Yuan 2020). In 2016, NDRC and National Energy Administration (NEA) issued several policy documents aimed at countering the rise in coal-powered plants, including a 'traffic-light system' for coal-power planning and a risk-management mechanism for the provinces for new coal-plant approvals (NEA 2016; GEM 2020).

Overcapacity and subsidies to the coal sector have received attention in the post-Paris period. Attempts to reduce overcapacity were made in 2017, when the NEA cancelled plans for constructing new coal-fired plants and closing outdated plants (NEA 2017b). The coal industry receives indirect and direct subsidies. These do not reflect the actual costs of coal to the economy and society, and subsidies for environmental abatement equipment reduce the cost of using coal (Hart et al. 2019). Moreover, provincial and local governments provide subsides to coal extraction operations - unlikely to incentivize the necessary shift in energy structure.

After Paris and with the stronger focus on air pollution, there was growing acceptance at the central level among policymakers and experts of the need to reduce coal consumption. However, there were challenges at the subnational level, in the provinces, where centrallevel policies are implemented. Among provincial leaders, there is some acceptance of the need to cap and reduce coal consumption to meet the mandatory coal reduction and air quality targets set by the central government, but the mentality of local leaders is largely fixed on coal-oriented industries. Local levels are expected to implement the policies set by the central government; targets are divided among the provinces (Schreurs 2017). The largest coal-producing provinces-Inner Mongolia (391 million tonnes/year), Shaanxi (210 million tonnes/year) and Shanxi (133 million tonnes/year) — continue to focus on coal mining and downstream coal power, coking and coal chemicals as the local economy and employment depend on this (NEA 2020d). Implementation of the coal-reduction targets in the provinces is extremely challenging, given their sheer size and limited capacity. For example: Shandong, the largest coal-consuming province, consumed $382 \mathrm{~m}$ tons of coal 
in 2018, whereas coal consumption in Germany was $217 \mathrm{~m}$ tons (Global Energy Statistics Yearbook 2019).

Local-level implementation may be hampered if policies are not well understood and if there is insufficient investment in local capacity building in education and scientific knowledge (Schreurs 2017, p.164). There are significant challenges entailed in reversing the trend whereby investors and local governments construct coal-fired power stations. Local-level governments may have a vested interest in trying to obstruct the implementation of costly policies that may impact the GDP growth of their province (Schreurs 2017, pp. 163-164). To deal with such challenges, six ministries (among them NDRC and NEA) have issued a notice on dealing with excess capacity in key sectors, including cleaner energy (NDRC 2020b; Myllyvirta 2020a). Energy security remains a dominant factor, and coal is perceived as the most reliable energy source.

\subsubsection{The BIG shift: technology and renewable energy}

While coal still dominated the energy mix, China embarked on a new path that would revolutionize the energy sector, at home and abroad. China is currently the 'largest producer, exporter and installer of solar panels, wind turbines, batteries and electric vehicles, placing it at the forefront of the global energy transition' (IRENA 2019, p. 40). The country is world leader in producing solar panels (66\%); and wind turbine manufacturers account for one-third of global supply (Helveston and Nahm 2019). To achieve this, policies promoting renewables have been important-especially the ten-year strategy (launched 2015) 'Made in China 2025', aimed at promoting innovation in ten core industries, including in the power sector (renewable energy, e.g. solar PV and wind (Korsnes 2020). These policies have triggered a major shift in the country's energy policy. Wind power is a clear example of Chinese leadership in developing and employing sources of renewable energy (Korsnes 2020).

The success of China's renewable energy development is due to investments and favourable policies, such as subsidies. Already in the 1980s, China had started to look into developing wind power (Yuan and Xi 2019). In 2005, the 'Renewable Energy Law' was issued, laying the foundations. By 2017, China's renewable energy investment accounted for more than $45 \%$ of the global total (IRENA 2019, p. 28). According to BP (2018), renewables consumption in China rose by $31 \%$ in 2017 , accounting for $36 \%$ of global growth in renewables. Moreover, patent filings are one way to assess countries' technological innovation capabilities (IRENA 2020). Of 13,160 global patents filed for renewable energy technologies in 2018, 7544 were in China, compared with 2,059 in the US (IRENA 2020). However, renewable energy is only a small fraction of the total energy picture, and there is room to develop. In 2019, China launched its first non-subsidised wind and PV solar power generation projects, with prices comparable to coal power (Korsnes 2020).

However, renewable energy deployment has also faced curtailment; under the electricity dispatch rule, thermal power plants are accorded priority over wind and solar plants. Excess capacity in thermal power means that solar and wind are not utilized. Moreover, wind and solar plants are sometimes built without transmission connections (Sandalow 2018). There are plans for addressing the curtailment challenge-including a mandatory renewable energy consumption mechanism with provincial quotas, and promotion of the interprovincial exchange of renewable energy. Some progress has been made; in 2018, wind-power curtailment was 7\%, a five percentage point improvement from 2017 (CREO 2019). 
To address some of the challenges with renewables, the national government (NDRC and NEA) has issued policies for promoting renewable energy. In 2018, NEA issued the 'Clean Energy Consumption Action Plan' (2018-2020), proposing national and provincial utilization rate targets for wind, PV and hydropower from 2018 to 2020 (DEA and ERI 2020). The Plan included control targets for wind and solar curtailment rates as well. There is a mandatory target for provinces for key renewable power developing regions; in 2016, NDRC/NEA set a minimum-hours purchasing requirement for wind and PV power (CREO 2019). Each province is formally required to purchase a minimum number of hours of utility-scale wind and PV power project output annually (NDRC 2016), but in many provinces this has not been achieved (China Energy Policy Newsletter June 2020), as was reported in the 2019 Renewable Power Monitoring and Assessment Report (NEA 2020). In March 2020, NEA issued the 2020 Wind and Solar PV Construction Plans, with a goal of transitioning to subsidy-free wind and PV. NDRC has also provided an outline for provincial mandatory renewable consumption plans (NDRC 2020).

New energy vehicles and equipment are also among the ten core industries in the 'Made in China 2025' strategy (Korsnes 2020). ${ }^{3}$ A 258 million-carpark in China contributes to global carbon emissions (Statista 2020). The sector affects local air quality heavily. One study found that motor vehicles and other mobile sources accounted for the greatest proportion of local atmospheric PM2.5 in Beijing (45\%), with diesel vehicles as the worst offenders (Deng and Yu 2018). Various policies have been adopted, including for newenergy vehicles (Korsnes 2020). China is currently the world's largest market for electric vehicles with 2.3 million units; it accounted for almost half of the global electric car stock in 2018 (IEA 2019). Canada, the USA, Germany and Japan have been central in providing bilateral funding and technology and entering into joint ventures with China on developing electric vehicles (EVs) and battery technologies (Malcomson 2020).

Developing nuclear power, a stated coal-substitution objective in the Energy Development Strategy Action Plan (2014-2020; State Council 2014), is on the rise. Classified as non-fossil energy, nuclear power will make up part of China's $15 \%$ objective of non-fossil energy by 2020. Although nuclear plant construction was halted in 2011 due to the Fukushima disaster in Japan, nuclear-plant construction picked up speed, and between 2013 and 2018 China opened 29 nuclear plants (Sandalow 2019). According to Chinese experts, nuclear power will also play an important role in the clean power transition, perhaps accounting for $28 \%$ of total power generation by 2050 (Jiang et al. 2018). China currently has 47 nuclear power units in operation and 11 units under construction; 10 units have been put into operation since 2018, including the first global projects of the Evolutionary Power Reactor and the AP1000 (a nuclear pressurized water reactor using advanced passive safety systems) (Xinhua news 2019). In its INDC (Intended Nationally Determined Contributions), China listed nuclear power as one tool towards low-carbon energy development and addressing climate change (NDRC 2015, p.7). The objective is to achieve installed nuclearpower capacity of 19.88 gigawatts-2.9 times that of 2005 .

\footnotetext{
3 'New energy vehicles' include battery electric vehicles, plug-in hybrid vehicles, fuel cell vehicles, hydrogen vehicles and other specific new technology vehicles.
} 


\section{Non-fossil future for China? (2020-2030-2060)}

President Xi Jinping's unexpected announcement on 22 September, 2020 that China will be carbon-neutral by 2060 could be a gamechanger. Moreover, China intends to peak its carbon emissions before 2030 and enhanced the NDC goal to reduce carbon intensity by 65\% compared to 2005 (NDRC 2015; Xinhua 2020b). Considerable uncertainty regarding the details remains but reaching the 2060 target will require hard work. How will China go about this? Here, we analyse some main trends and drivers for China in the coming decades. The Fifth Plenum meeting of the Communist Party of China (CPC) Central Committee (concluded on 29 October 2020) cemented the need to accelerate the promotion of green and low-carbon development (Xinhua 2020a, b). Equally important, 2030 targets will be significant for China to peak emissions and become a "great modern socialist nation" by 2035 (Xinhua 2020a, b).

\subsection{Energy and climate in the 2060 context}

Currently, a plan for achieving the 2060 goal is not on the table, but it is expected that the coming FYPs will set concrete, binding goals. The first goal to be met is the peaking of emissions before 2030. Recently, Tsinghua University issued a report commissioned by the government, with a roadmap of pathways for China. Key recommendations are absolute caps in the 14th FYP, peaking emissions by 2025, and updating the 2030 NDC goals (He 2020; Reklev 2020a). Further, a gradual transition with a rapid acceleration after 2035 is recommended (Bloomberg 2020). The report has received considerable attention inside and outside China, as it has been compiled by the country's top climate experts. Notably, the work was supervised by former climate change ambassador and negotiator Xie Zhenhua, which is likely to carry a certain weight. ${ }^{4}$ According to the report roadmap, 'by 2050 China must achieve net zero carbon dioxide emissions, with emissions of all greenhouse gases down $90 \%$ on 2020 levels, if it is to achieve carbon neutrality by 2060' (Ma 2020). It presents a $2{ }^{\circ} \mathrm{C}$ scenario, with the share of coal falling to less than $10 \%$ by 2050 and non-fossil energy accounting for $70 \%$. Under the $1.5{ }^{\circ} \mathrm{C}$ scenario, non-fossil will make up $85 \%$ of the energy mix by 2050 and coal less than $5 \%$ (He 2020). However, it is not clear whether the objective covers GHGs in general, or only carbon (The Economist 2020; Climate Action Tracker 2020; Reklev and Garside 2020).

In the shorter term, the crucial issues in the upcoming 14th FYP (2021-25) are whether China will be able to accelerate its shift away from a coal-based energy system, reducing coal use and transiting to non-fossil energy. This would mean halting the current push towards more coal power in the provinces, linked to the relaxation of the traffic-light system that allows for more coal-powered plants (NEA 2020c; China Energy Portal 2020; Myllyvirta et al. 2020a, b, c). China is currently preparing a new energy law (NEA 2020), now out for public comment, to ensure that climate targets are met. The $15^{\text {th }}$ FYP (2026-2030) will be equally important as the NDC's goal of peaking emissions before 2030 approaches.

Debate is underway on energy targets in the 14th FYP for energy development; discussions will now have to reflect the new 2030 and 2060 objectives. The sector-specific fiveyear plans, expected in 2021-22, will include detailed targets for various energy sources, power-generating capacity, share of coal in total energy, and other matters. China's growing

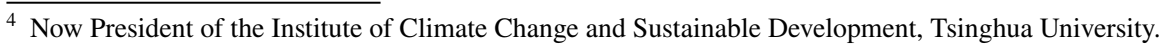


oil consumption is another fossil challenge to be tackled. Oil import dependency reached $72 \%$ in 2018, a 2.4\% increase from 2017 (CREO 2019). Import dependency on gas rose to $43 \%$ in 2018. Concerns about national energy security are increasing (BP 2019; CREO 2019).

There is also the question of implementing policies among actors with diverging interests. China Electricity Council (CEC), the industrial body that looks after power utility interests, and State Grid, the influential network operator, traditionally lobby for coal. Both are powerful actors in the energy sector, which might result in continued emphasis on coal. The Ministry of Ecology and Environment (MEE), in charge of both climate change and environmental issues, would be expected to contribute to better enforcement of energy and climate policies in the coal sector. With its inspection and monitoring experience in the provinces, this ministry can follow up closely on implementation. Additionally, the consolidation of environmental responsibilities in one ministry could help to align various environmental strategies and policies, including the carbon market. Substantial reforms in the power sector are being implemented in parallel with the carbon market, which may positively impact carbon trading (IEA 2020). By setting stringent benchmarks in China's ETS, the market can play a significant role in reducing emissions, though after a few years in operation. However, responsibility for energy policy remains with the NDRC and the National Energy Administration, necessitating close coordination among MEE, NDRC and NEA. The NDRC would still be able to influence climate policy through its energy policy (Hart et al. 2019). The recent 2060 carbon neutrality goal has given new momentum to energy and climate efforts in China, so any relaxation of coal policies would seem to be at odds with national climate goals.

\subsection{On technology and innovation}

To reach the 2030 and 2060 goals, technology and innovation in the energy sector are crucial. China's leaders are determined that innovation happen in China, aspiring to make China a leading nation on innovation, and achieve greater technological independence (Korsnes 2020). Additionally, in the wake of the Covid-19 pandemic and deteriorating relations with the USA (as well as strained relations with the EU and Western countries), China's desire to be less dependent on imports might trigger a move towards renewable technologies, and there are such trends as discussed below.

The 2020 Covid-19 pandemic has affected car sales globally, making it difficult to conclude on the effect of vehicle market trends on China's EV industry. Although Tesla was briefly closed due to Covid-19, it reopened its Shanghai factory in February (CNA 2020). China's battery industry is still going strong and is being globalized. The wind and solar industries are expected to expand as they become more competitive with coal prices (CREO 2019). Demand for offshore wind technologies is growing; China is one of the upand-coming markets that accounted for $76 \%$ of total global demand for offshore wind technologies in 2019 (IRENA 2020; Wood Mackenzie 2020). The IEA $(2019,2020)$ in its EV Outlook China maintains that China retains its world lead with $57 \%$ share of the EV market in 2030, with 3.4 million electric cars in China in 2019, a $46 \%$ increase from the previous year. The subsidy scheme was extended through 2022 due to a drop in sales in 2019. For infrastructure building, China continues to lead in the rollout of publicly accessible chargers. Cities in China are also driving the innovation change, as in Shenzhen (pop. 12 million), with a fully electric bus fleet of 16,000 vehicles. In sum, there is reason for cautious 
optimism that technological change may serve as a major modifier of China's emissions growth.

As to the economy in general, in early 2020, China's economy was hit by the Covid-19 pandemic, and emissions fell. At the National People's Congress (NPC) in 2020 no economic goals for the coming year were set, due to uncertainties. This was viewed as positive for climate change, as well as the need to strike a balance between economic growth and other socio-economic considerations. Unexpectedly, the National Bureau of Statistics reported that the economy was up by $4.9 \%$ for the third quarter (NBS 2020b). The authorities have presented stimulus packages, almost $\$ 430$ billion in stimulus payments to help the economy recover from the coronavirus crisis among them infrastructure investment, such as approval of two new nuclear plants and banking assistance to finance small businesses including infrastructure investment (Tang 2020). The automobile market has been in focus here, with measures such as relaxing auto quota permits (IEA 2020). China's longterm economic development plan has been projected to reach xiaokang shehui (relatively well-off society with no poverty) by the end of 2020; by 2035, to become a basic modern economy and an affluent society by 2050 . The CPC Central Committee meeting communique identified plans for the economy; it endorsed and deliberated on the 14th five-year economic plan and a blueprint for China's development until 2035, heralded as the year of 'achieving socialist modernization' (The Economist 2020; Xinhua 2020a, b).

\section{Concluding remarks}

The article has examined how 30 years of development in domestic energy and climate policies influenced long-term trends in China and what this could imply for future climate policies. It has illustrated how different forces shape China's climate long-term policy trends and shown that the mix of policy instruments addressing GHG emissions, energy and climate policies, have gradually become more ambitious and varied. From viewing climate change as a mere scientific policy issue in the 1990s, policies have evolved to include targeted energy efficiency and air pollution goals, employment of market instruments (away from command-and-control approaches), to an emphasis on green growth and renewables. Policy development culminated in 2020 with the 2060 carbon neutrality goal, which will require highly ambitious policies in the years to come.

The Paris Agreement was significant for China. China submitted its Nationally Determined Contribution (NDC) objectives that were aligned with the five-year planning cycle, clearly linking domestic and global goals. Policies after Paris show a growing emphasis on green growth promoting technological innovation and renewables, which triggered a shift in the country's energy policy. To this end, China has prioritized measures, laws and policies to reduce coal consumption and develop renewable energy, especially solar and wind. These efforts have yielded results: China has emerged as the world leader in renewable energy, and also leads in electric vehicle use and battery production. With the Covid-19 pandemic has come a resurgence in the coal sector, as the country seeks to return to normal. Climate change ranks high on the political agenda, but energy security, is a concern, and coal is still regarded the most reliable source by many stakeholders.

However, there is reason for optimism, not least given the unexpected 2060 goal. To achieve it, and to break China's long-term emissions trend, action will have to begin with the upcoming 14th FYP. This will be critical for accelerating the energy transition. Major areas to follow in the next few years will be in technology and innovation that contribute to 
the reduction of $\mathrm{CO}_{2}$. The development of energy-efficient technologies, as well as further non-fossil development of solar and wind power, will be crucial for tackling emissions. Importantly, China needs to set a cap on coal in its energy-transition strategy. China's $14^{\text {th }}$ FYP should be an important first step towards this goal. Future research could contribute to learning from policy implementation experiences to further strengthen energy and climate policies, and to identify policy mixes needed to reach the carbon neutrality goal.

Acknowledgements The author wants to thank two reviewers, the special feature team, Joyeeta Gupta and Steinar Andresen for valuable comments.

\section{References}

Ahlers, A.L. \& Shen, Yongdong. (2018). Breathe easy? Local nuances of authoritarian environmentalism in China's battle against air pollution, The China Quarterly, 234, June 2018, pp. 299-319. https://doi. org/10.1017/S0305741017001370

Andresen, S, Bang, G., Skjærseth, J.B. and A. Underdal. (2020). Achieving the ambitious targets of the Paris Agreement: The role of key actors, Vol 1, Special Feature, International Environmental Agreements: Politics, Law and Economics

Bloomberg News. (2020). Next China: Under threat, 12 June, Retrieved June 29, 2020 from https://www. bloombermg.com/news/newsletters/2020-06-12/next-china-under-threat

BP Statistical Review. (2018), China's energy market in 2017. https://www.bp.com/content/dam/bp/busin ess-sites/en/global/corporate/pdfs/energy-economics/statistical-review/bp-stats-review-2018-china -insights.pdf

BP Statistical Review. (2019). China's energy market in 2018. Retrieved October 15, 2019 from https:// www.bp.com/content/dam/bp/business-sites/en/global/corporate/pdfs/energy-economics/statistica 1-review/bp-stats-review-2019-china-insights.pdf

Central Committee of the Chinese Communist Party (CCPCC). (2013). Communique of the third plenary session of the 18th Chinese Communist Party Central Committee. Retrieved October 18, 2017 http:// www.china.org.cn/china/third_plenary_session/2014-01/15/content_31203056.htm

Chai Yumin, Fu Sha, Yan Yue, Fan Xing \& Wen Xinyuan. (2018). Implementation, update and convergence of national independent contributions to climate change, China Development Observation 28 May. http://www.chinado.cn/?p=6252

China Renewable Energy Outlook (CREO). (2017). http://boostre.cnrec.org.cn/wp-content/uploa ds/2017/10/CREO-2017-EN-20171113-1.pdf

China Renewable Energy Outlook (CREO). (2018). Microsoft Word-CREO 2017 1111-WORD 2013 (solarbusinesshub.com)

China Renewable Energy Outlook (CREO). (2019). Microsoft Word-CREO2019-Summary 191201-final-clean--civilisation (dena.de).

Climate Action Tracker. (2020). Country Summary. https://climateactiontracker.org/countries/china/ Accessed 15 October 2020

Crippa, M., Oreggioni, G., Guizzardi, D., Muntean, M., Schaaf, E., Lo Vullo, E., Solazzo, E., et al. (2019). Fossil $\mathrm{CO}_{2}$ and GHG emissions of all world countries: 2019 Report, Publications Office of the European Union, Luxembourg, 2019, ISBN 978-92-76-11100-9, doi:https://doi.org/10.2760/687800, JRC117610.

CNA. (2020). Shanghai to help Tesla resume production amid coronavirus spread. 9 February. https:// www.channelnewsasia.com/news/business/shanghai-to-help-tesla-resume-production-amid-coronaviru s-spread-12411198

Danish Energy Agency (DEA) \& ERI (2020). China Energy Policy Newsletter, Boosting renewable energy as part of China's energy revolution, June.

Deng, Q. \& Yu, H.Z. (2018). Motor vehicles account for majority of Beijing's PM 2.5 pollution, Beijing News 14 May, Retrieved June 21, 2020 from http://www.bjnews.com.cn/news/2018/05/14/486842.html

Eikeland, P. O., \& Skjærseth, J. B. (2019). The politics of low carbon innovation: The EU Strategic Energy Technology Plan. Cham: PalgraveMacmillan. 
The Economist. (2018). Seeking salvation: Forty years after Deng opened China, reformists are cowed. 6 December. Retrieved December 7, 2018 from https://www.economist.com/china/2018/12/08/forty -years-after-deng-opened-china-reformists-are-cowed

The Economist. (2020). China's most senior officials endorse economic plans for years ahead. 31 October, https://www.economist.com/china/2020/10/31/chinas-most-senior-officials-endors-economic-plans -for-years-ahead

Global Energy Monitor (GEM). (2020). China's restrictions on development of coal-fired power capacity, 20 March. Retrieved June 26, 2020 from https://www.gem.wiki/China\%27s_Restrictions_on_Devel opment_of_Coal-Fired_Power_Capacity

Global Energy Statistics Yearbook. (2019). https://yearbook.enerdata.net/coal-lignite/coal-world-consu mption-data.html

gov.cn. (2019). Zhongguo zhengfu wang (Li Keqiang presided over the National Leading Group Meeting on Climate Change, Energy Conservation and Emission Reduction), 11 July. Retrieved November 22, 2019 from http://www.gov.cn/premier/2019-07/11/content_5408442.htm

Green, F., \& Stern, N. (2016). China's changing economy: Implications for its carbon dioxide emissions. Climate Policy, 17(4), 423-442.

Hart, C., Zhu, J.Y. \& Ying, J.H. (2019). Mapping China's Climate and Energy Policies. December 2018 edn. Retrieved June 21, 2020 from https://assets.publishing.service.gov.uk/government/uploads/syste m/uploads/attachment_data/file/786518/China_Climate_Map_Public_Secured_2019-3-1.pdf

He, J.K. (2020). Launch of the outcome of the research on China's Long-term Low-carbon Development Strategy and Pathway, Institute of Climate Change and Sustainable Development, Tsinghua University, 12 October. https://mp.weixin.qq.com/s/S_8ajdq963YL7X3sRJSWGg

Heggelund, G., \& Nadin, R. (2017). Climate change policy and governance. In E. Sternfeld (Ed.), Routledge Handbook of Environmental Policy in China (pp. 97-112). London: Routledge.

Heggelund, G., Stensdal, I., Duan, M. S., \& Wettestad, J. (2019). China's development of ETS as a GHG mitigating policy tool: a case of diffusion or domestic drivers? Review of Policy Research. https://doi. org/10.1111/ropr.12328.

Helveston, J., \& Nahm, J. (2019). China's key role in scaling low-carbon energy technologies. Science, 366(6467), 794-796. https://doi.org/10.1126/science.aaz1014.

Hilton, I., \& Kerr, O. (2017). The Paris Agreement: China's 'New Normal' role in international climate negotiations. Climate Policy, 17(1), 48-58. https://doi.org/10.1080/14693062.2016.1228521.

IEA. (2019). Coal Consumption by Sector in China, 2008-2024, Paris: IEA. https://www.iea.org/data-andstatistics/charts/coal-consumption-by-sector-in-china-2008-2024

IEA. (2020). China's Emissions Trading Scheme, Designing efficient allowance allocation, Retrieved 29, 2020 from https://www.iea.org/reports/chinas-emissions-trading-scheme

IRENA. (2019). Global EV Outlook, Scaling-up the transition to electric mobility https://webstore.iea.org/ download/direct/2807?fileName=Global_EV_Outlook_2019.pdf

IRENA. (2020). Global Renewables Outlook: Energy transformation 2050. Retieved June 26, 2020 from https://www.irena.org/publications/2020/Apr/Global-Renewables-Outlook-2020

Jiang, K. J., He, C. M., Yu, X. Y., Jiang, W. Y., Li, H., \& Liu, J. (2018). Transition scenarios of power generation in China under global $2{ }^{\circ} \mathrm{C}$ and $1.5^{\circ} \mathrm{C}$ targets. Global Energy Interconnection, 1(4), 477-486. https://doi.org/10.14171/j.2096-5117.gei.2018.04.008.

Kopra, S. (2019). China and great power responsibility for climate change. London: Routledge.

Korsnes, M. (2020). Wind and solar energy transition in China. London: Routledge.

Le Quéré, C., Andrew, R. M., Friedlingstein, P., Sitch, S., Pongratz, J., Manning, A. C., \& Korsbakken, J. I. (2018). Global carbon budget 2017. Earth System Science Data, 10, 405-448. https://doi.org/10.5194/ essd-10-405-2018.

Lin, J., Fridley, D., Lu, H. Y., Price, L.K. \& Zhou, N. (2018). Near-term Trends in China's Coal Consumption, LBNL-2001145, http://etapublications.lbl.gov/sites/default/files/china_coal_peak_analysis_lbnlr eport_0.pdf

Ma, T.J. (2020). Researchers unveil roadmap for a carbon neutral China by 2060. China Dialogue, 13. https ://chinadialogue.net/en/climate/researchers-unveil-roadmap-for-a-carbon-neutral-china-by-2060/

Malcomson, S. (2020) How China became the world's leader in green energy. And what decoupling could cost the environment. Foreign Affairs, 28 February, https://www.foreignaffairs.com/articles/china /2020-02-28/how-china-became-worlds-leader-green-energy

Ministry of Ecology and Environment (MEE). (2021). Carbon Emissions Trading Management Measures (for Trial Implementation (mee.gov.cn)

Ministry of Ecology and Environment (MEE). (2019). UN Climate Action Summit: China's Position and Action 17 September http://english.mee.gov.cn/News_service/news_release/201909/t20190917_73405 1.shtml, http://qhs.mee.gov.cn/qqqhzl/201909/t20190917_734045.shtml (in Chinese) 
Myllyvirta, L. (2020a). Analysis: China's CO2 emissions surged past pre-coronavirus levels in May, Carbon Brief, 29 June. Retrieved June 29, 2020 from https:/www.carbonbrief.org/analysis-chinas-co2-emiss ions-surged-past-pre-coronavirus-levels-in-may. Accessed 29 June 2020

Myllyvirta, L. (2020b). Analysis: Coronavirus has temporarily reduced China's CO2 emissions by a quarter. Carbon Brief, 19 February. https://www.carbonbrief.org/analysis-coronavirus-has-tempo rarily-reduced-chinas-co2-emissions-by-a-quarter

Myllyvirta, L. (2020c). China's 2060 climate pledge: long-awaited breakthrough or sugar-coating another decade of rising emissions? 23 September. https://energyandcleanair.org/china-2060-carbo n-neutrality/

Myllyvirta, L., Zhang, Shuwei \& Shen, Xinyi (2020). Analysis: Will China build hundreds of new coal plants in the 2020s?, Carbon Brief, 24 March. https://www.carbonbrief.org/analysis-will-china -build-hundreds-of-new-coal-plants-in-the-2020s

National Bureau of Statistics (NBS 2020a). Statistical Communiqué of the People's Republic of China on the 2019 National Economic and Social Development, 28 February http://www.stats.gov.cn/tjsj/ zxfb/202002/t20200228_1728913.html

National Bureau of Statistics (NBS 2020b). Economic Growth of the First Three Quarters Shifted from Negative to Positive, Press Release, 19 October http://www.stats.gov.cn/english/PressRelea se/202010/t20201019_1794616.html

National Development and Reform Commission (NDRC). (2007). China's National Climate Change Programme, June 2007. Retieved March 6, 2017 from http://www.ccchina.gov.cn/WebSite/CCChina/ UpFile/File188.pdf

NDRC (2010). Department of Climate Change National Development and Reform Commission of China, Copenhagen Accord, 28 January 2010. Retrieved October 6, 2017 from http://unfccc.int/ files/meetings/cop_15/copenhagen_accord/application/pdf/chinacphaccord_app2.pdf

NDRC. (2016). Notice of the National Development and Reform Commission on Distributing the "Administrative Measures for the Full-Supply Safeguard of Renewable Energy Power Generation"[2016] No. 625, 28 March, http://www.nea.gov.cn/2016-03/28/c_135230445.htm

NDRC (2011). Notice on Carrying out Carbon Emissions Trading Pilots. NDRC's Climate department notice no. 2601. Retrieved July 13, 2016 from http://www.sdpc.gov.cn/zcfb/zcfbtz/201201/t2012 0113_456506.html (in Chinese).

NDRC (2015). China's Intended Nationally Determined Contributions Enhanced Actions on Climate Change. (3 June). Retrieved May 16, 2017 from http://www4.unfecc.int/submissions/INDC/Publi shed\%20Documents/China/1/China's\%20INDC\%20-\%20on\%2030\%20June\%202015.pdf

NDRC (2017). China's Policies and Actions for Addressing Climate Change 2017. Retrieved 8, 2018 from http://www.ndrc.gov.cn/gzdt/201710/W020171101318500878867.pdf

NDRC (2020b). Notice on Doing a Good Job of Resolving Excess Capacity in Key Areas in 2020 https:// www.ndrc.gov.cn/xxgk/zcfb/tz/202006/t20200618_1231503.html

NDRC/NEA (2017). National Strategy on Energy Production and Consumption Revolution (2016-2030), https://chinaenergyportal.org/energy-production-consumption-transition-strategy-2016-2030/

NDRC/NEA. (2020). Notice to Issue the Outline to Guide the Formulation of Provincial Renewable Power Consumption Plans, No. 1814 March

National Energy Administration (NEA). (2016). Notice of the National Energy Administration on the establishment of coal mine power planning and construction risk warning mechanism and the release of 2019 coal power planning and construction risk warning, 7 December, No. 42, http:// www.waizi.org.cn/law/11730.html

National Energy Administration (NEA). (2017a) 13th FYP for Energy Development December 2016. Retrieved December 24, 2017 from http://www.ndrc.gov.cn/zcfb/zcfbghwb/201701/W020170117 350627940556.pdf

National Energy Administration (NEA). (2017b). Total renewable energy investment during the 13th Five-Year Plan period will reach 2.5 trillion yuan, 5 January, http://www.nea.gov.cn/201701/05/c_135956835.htm

National Energy Administration (NEA). (2020a). Notice of the National Energy Administration on matters 'related to the construction of wind power and photovoltaic power generation projects in 2020 , 5 March, Retrieved June 21, 2020 from http://zfxxgk.nea.gov.cn/2020-03/05/c_138862190.htm

National Energy Administration (NEA) (2020b). Announcement of the National Energy Administration on the public solicitation of the "Energy Law of the People's Republic of China (Draft for Comment)" 10 April, Retrieved June 21, 2020 from http://www.nea.gov.cn/2020-04/10/c_138963212.htm

National Energy Administration NEA (2020c). Circular on 2023 risk and early warning for coal power planning and construction 
National Energy Administration NEA. (2020d). China has 52 coal mines producing 10 million tonnes, Retrieved August 6, 2020 from http://www.nea.gov.cn/2020-07/13/c_139209106.htm

Olivier, J.G.J. \& Peters, J.A.H.W. (2018), Trends in global CO2 and total greenhouse gas emissions: 2018 report. PBL Netherlands Environmental Assessment Agency, The Hague Retrieved January 28, 2019 from https://www.pbl.nl/sites/default/files/cms/publicaties/pbl-2018-trends-in-global-co2and-total-greenhouse-gas-emissons-2018-report_3125.pdf

Reklev, S. (2020a). Major report urges China to cap CO2 emissions by 2025, strengthen NDC, Carbon Pulse, 12 October, https://carbon-pulse.com/111703/

Reklev, S. (2020b). China releases draft rules for national CO2 emissions trading scheme, Carbon Pulse, 3 November, https://carbon-pulse.com/113565/

Reklev, S. \& Garside, B. (2020). China commits to peaking GHG emissions before 2030, carbon neutrality before 2060, Carbon Pulse, 22 September, https://carbon-pulse.com/109866/

Sandalow, D. (2018). Guide to Chinese Climate Policy 2018, SIPA, Center on Global Energy Policy, Columbia University, Retrieved December 5, 2018 from https://energypolicy.columbia.edu/sites/defau 1t/files/pictures/Guide\%20to\%20Chinese\%20Climate\%20Policy\%207-27-18.pdf

Schreurs, M. (2017). Multi-level climate governance in China. Environmental Policy and Governance, 27, 163-174. https://doi.org/10.1002/eet.1751.

State Council (2014) State Council on the issuance of Energy Development Strategy Action Plan (2014-2020), 31 http://www.gov.cn/zhengce/content/2014-11/19/content_9222.htm.

State Council (2016a). The People's Republic of China's 13th Five-Year Plan of National Economic and Social Development (2016-2020). Retrieved December 15, 2017 from http://news.xinhuanet.com/polit ics/2016lh/2016-03/17/c_1118366322.htm

State Council (2016b). State Council Notice on the Work Plan for Controlling GHG emissions in the 13th FYP (27 October). Retrieved November 4, 2016 http://www.gov.cn/zhengce/content/2016-11/04/conte nt_5128619.htm

State Council (2018). State Council Notice on the three-year action plan to win the blue skies defence war 27 June. Retrieved July 5, 2018 from http://www.legaldaily.com.cn/index_article/content/2018-07/03/ content_7585363.htm

Statista (2020). Car parc in China from 2009 to 2019. https://www.statista.com/statistics/285306/number-ofcar-owners-in-china/

Tang, F. (2020). China coronavirus stimulus: what measures have been used to combat the economic impact of Covid-19? South China Morning Post, 8 May. Retrieved June 30, 2020 from https://www.scmp.com/ economy/china-economy/article/3083268/china-coronavirus-stimulus-what-measures-have-been-used

Wood, M. (2020). Record amount of wind turbine capacity ordered globally in 2019. 5 March https://www. woodmac.com/press-releases/record-amount-of-wind-turbine-capacity-ordered-globally-in-2019/

Xinhua. (2019). Nuclear energy to play bigger role in combating climate change: Chinese diplomat, 9 October, Retrieved October 20 from http://www.xinhuanet.com/english/2019-10/09/c_138457710.htm

Xinhua. (2020). Communiqué of the Fifth Plenary Session of the 19th Central Committee of the Communist Party of China (in Chinese), http://www.xinhuanet.com/politics/2020-10/29/c_1126674147.htm

Xinhua. (2020b). Full Text: Remarks by Chinese President Xi Jinping at Climate Ambition Summit - Xinhua I English.news.cn (xinhuanet.com)

Yuan, J.H. (2020). 2023 Coal-fired power plant planning and construction early warning green all over, reproduce the Great Leap Forward? (2023) Caixin 6 March, Retrieved June 17, 2020 from https://opini on.caixin.com/2020-03-06/101524628.html

Yuan, L. Y., \& Xi, J. C. (2019). Review on China's wind power policy (1986-2017). Environmental Science and Pollution Research, 26, 25387-25398. https://doi.org/10.1007/s11356-019-05540-0.

Zhang, H. B., Dai, H. C., Lai, H. X., \& Wang, W. T. (2017). U.S. withdrawal from the Paris Agreement: Reasons, impacts and China's response. Advances in Climate Change Research. https://doi. org/10.1016/j.accre.2017.09.002.

Zhang J.J. \& Wang, W.W. (2020). China's energy law could help address the Belt and Road's climate impact, China Dialogue 22 June, Retrieved June 29, 2020 from https://chinadialogue.net/en/energy/ chinas-energy-law-could-help-address-the-belt-and-roads-climate-impact/

Publisher's Note Springer Nature remains neutral with regard to jurisdictional claims in published maps and institutional affiliations. 